\title{
Sacroiliac Abscess Due to Brucella
}

\section{Brusellaya Bağlı Sakroiliak Abse}

\author{
Serpil Tuna', Özge Turhan² \\ 'Department of Physical Medicine and Rehabilitation, Akdeniz University Medical Faculty Hospital, Antalya, Turkey \\ 2Department of Infectious Disease, Akdeniz University Medical Faculty Hospital, Antalya, Turkey
}

\section{ABSTRACT}

Introduction: Brucellosis is an infectious disease caused by gramnegative coccobacillus. Brucellosis, which is a disease common all over the world, is endemic in some regions. Musculoskeletal involvement is the most common complication of the disease, which can affect various organs and tissues.

Case Report: Here, we report a case of brucellosis who became wheelchair-dependent due to low back and hip pain. Multiple sacroiliac joint abscesses were determined in her radiological examination, and she was diagnosed with septic sacroiliitis. Her symptoms resolved dramatically with combined therapy, and she started to walk again

Conclusion: It should be kept in mind that brucellosis may present with severe complications, and especially, musculoskeletal involvement should be treated with triplet combined therapy.

Keywords: Brucellosis, septic sacroiliitis, sacroiliac abscess

Received: 20.09.2013 Accepted: 23.12.2013

\section{ÖZET}

Giriş: Brusellozis, gram negatif kokobasillerin neden olduğu enfeksiyöz bir hastalıktır. Tüm dünyada yaygın olarak görülen brusellozis, bazı bölgelerde endemiktir. Pek çok organ ve dokuları tutabilen hastalığın en sık görülen komplikasyonu kas iskelet sistemi tutulumudur.

Olgu Sunumu: Biz burada bel ve kalça ağrısı nedeniyle tekerlekli sandaleye bağımlı hale gelen bir brusellozis vakasını sunduk. Hastanın sakrolilak eklemlerinde multipl abseler saptandı ve septik sakroileit tanısı koyuldu. Kombine tedavi ile şikayetleri dramatik olarak düzelen hasta tekrar mobilize oldu.

Sonuç: Brusellozisin ciddi komplikasyonlarla karşımıza çıkabileceği ve özellikle kas iskelet sistemi tutulumlarında üçlü kombine tedavi ile komplikasyonların önlenebileceği akılda tutulmalıdır.

Anahtar Kelimeler: Brusellozis, septik sakroileit, sakroiliak abse

Geliş Tarihi: 20.09.2013 Kabul Tarihi: 23.12.2013

\section{Giriş}

Brusellozis, gram negatif Brusella basillerinin neden olduğu zoonotik bir hastalıktır. Tüm dünyada yaygın olarak görülen hastalık belirli bazı bölgelerde endemiler yapmaktadır. Her yıl yaklaşık yarım milyon insanın hastalıkla temas ettiği tahmin edilmektedir (1). Brusellozis, özellikle hayvanları etkileyen bir hastalıktır ve hayvanlardan insanlara enfekte süt ve süt ürünlerinin tüketilmesi veya direk temas ile bulaşır (2). Pek çok organ ve sistemleri tutabilen Brusellozis de, osteoartiküler tutulum en sık karşılaşılan komplikasyondur ve sıklıkla sakroiliak eklem ve vertebra tutulumu görülmektedir.(3,4) Bunu büyük periferik eklem tutulumları izler. Septik artrit ise nadiren görülür (2).

Bu yazı da burusella basiline bağlı, septik sakroileit ve sakroiliak abse gelişen nadir bir vaka sunulmuştur.

\section{Olgu Sunumu}

49 yaşında erkek hasta bel ve sol kalçada şiddetli ağrı, yürüyememe şikayetleri ile hastanemize başvurdu. Öyküsünde 10 gün önce ateş ve sol kalçada ağrı şikayetleriyle dış merkezde bruselloz tanısı koyularak doksisiklin (Tetradox; Fako Illaçları A.Ş., İstanbul, Türkiye) (2×100 mg /gün PO) ve stretomisin sülfat (Streptomycine flakon; Ibrahim Ethem Ulagay illaç Sanayi Türk A.Ş, İstanbul, Türkiye) (1 gr/ gün IM) tedavisi başlandığı öğrenildi. Aldığı tedaviye rağmen hastanın şikayetleri ilerlemiş ve yürüyemez hale gelmişti. Özgeçmiş̧inde kronik hepatit B nedeniyle 6 yıldır tenovofir (Viread; Gilead Sciences Illaç Tic. Ltd. Şti., Cork, İrlanda) (245mg/gün) kullanımı vardı.

\section{Address for Correspondence/Yazışma Adresi:}

Serpil Tuna, Department of Physical Medicine and Rehabilitation, Akdeniz University Medical Faculty Hospital, Antalya, Turkey.

Phone: +905052332647 E-mail: dr.serpiltuna07@hotmail.com 


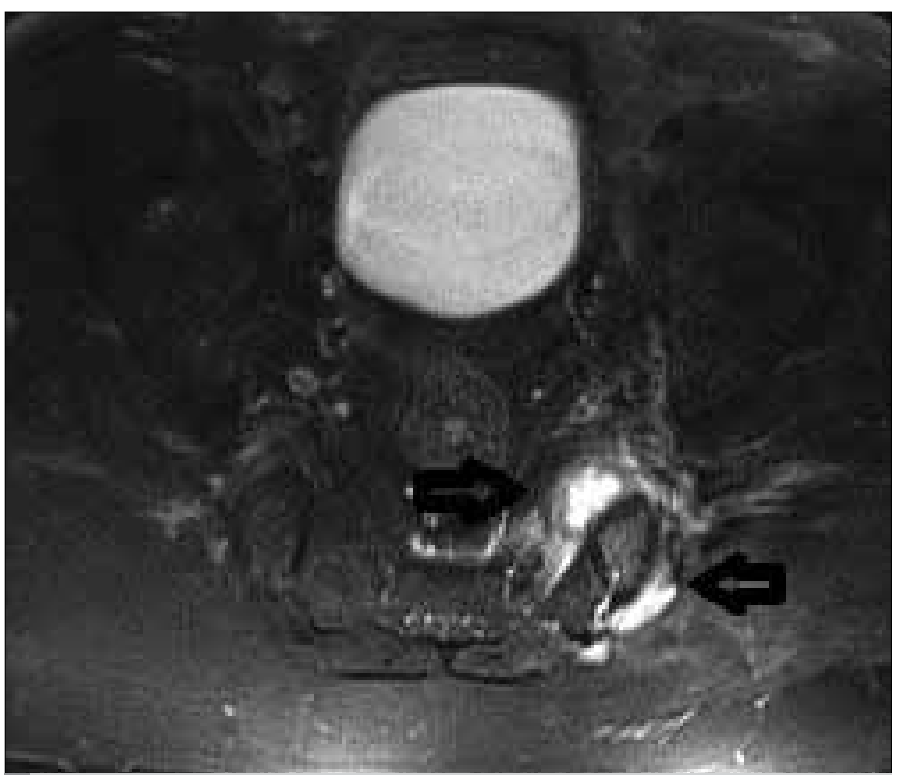

Sekil 1. Sakroiliak MR

Sistemik muayenesinde arteriyal kan basınc (TA):120/80 mm/Hg ateş: $36^{\circ} \mathrm{C}$ ölçüldü. Lenfadenopati ve hepatosplenomegali saptanmadı. Batın Ultrasonografi (USG)'de dalak 117 mm ölçüldü. Kas iskelet sistemi muayenesinde bel ve sol kalça hareketleri ağrılı ve hareket kısıtlıı̆ı vardı. Sol sakroiliak eklem ağrılı, hassas ve sakroiliak kompresyon ve distraksiyon testleri (+) idi.

Laboratuar tetkiklerinde eritrosit sedimentasyon hızı (ESH): 96 mm/ saat, C-reaktif protein (CRP): 3,2 mg/dL, pansitopenisi vardı. Karaciğer fonksiyon testleri (ALT: Alanin aminotransferaz, AST: Aspartat aminotransferaz) yüksekti. Brusella tüp aglütinasyon testi: 1/2560(+) ve brusella immuncapture aglütinasyon testi:1/640(+) idi.

Lumbosakral ve torakal Manyetik Rezonans Görüntüleme (MRG)'de spondilodiskit bulgusuna rastlanmadı. Sakroiliak MRG'da sol sakroiliak eklem inferior kesiminde anteroposterior komşuluğunda en büyüğü $1,5 \times 2 \mathrm{~cm}$ ve süperior kesiminde $1 \mathrm{~cm}$ boyutunda apse oluşumları saptandı ve septik artrit lehine yorumlandı. Lokalizasyonu ve küçük boyutta olması nedeniyle boşaltım düşünülmedi.

Brusella serolojisi pozitif olan hasta 10 gündür doksisiklin ( $2 \times 100 \mathrm{mg}$ /gün PO) ve stretomisin (1 gr/gün IM) tedavisi almaktaydı. Tedavisine rifampisin (Rifadin; Nobelfarma Illaç San. A.Ş., Düzce,Türkiye) (1X600 mg/gün PO) eklenerek üçlü tedaviye geçildi. Dış merkezde başlanmış olan streptomisin 14 güne tamamlanınca kesilerek sülfametoksazol-trimetoprim (Bactrim fort; Roche Müstahzarları Sanayi Anonim Sirketi, Kocaeli, Türkiye) (800 mg/160 mg 3x1/gün $\mathrm{PO}$ ) başlandı. Hastanın pansitopenisi düzeldi.

Hastaya, enfeksiyon hastalıkları kliniğinde yattığı süre boyunca, fizyoterapist tarafindan, bel ve kalçaya eklem hareket açılkı̆̆ı̆ı ve kas gücünü korumak için pasif eklem hareket açıklı̆ı egzersizleri ve izometrik egzersizler yaptırıldı. Tedavi ile ağrıları azalan hastaya yürüme eğitimi verildi. Hastanın şikayetleri büyük oranda geriledi ve tekrar mobilize oldu.

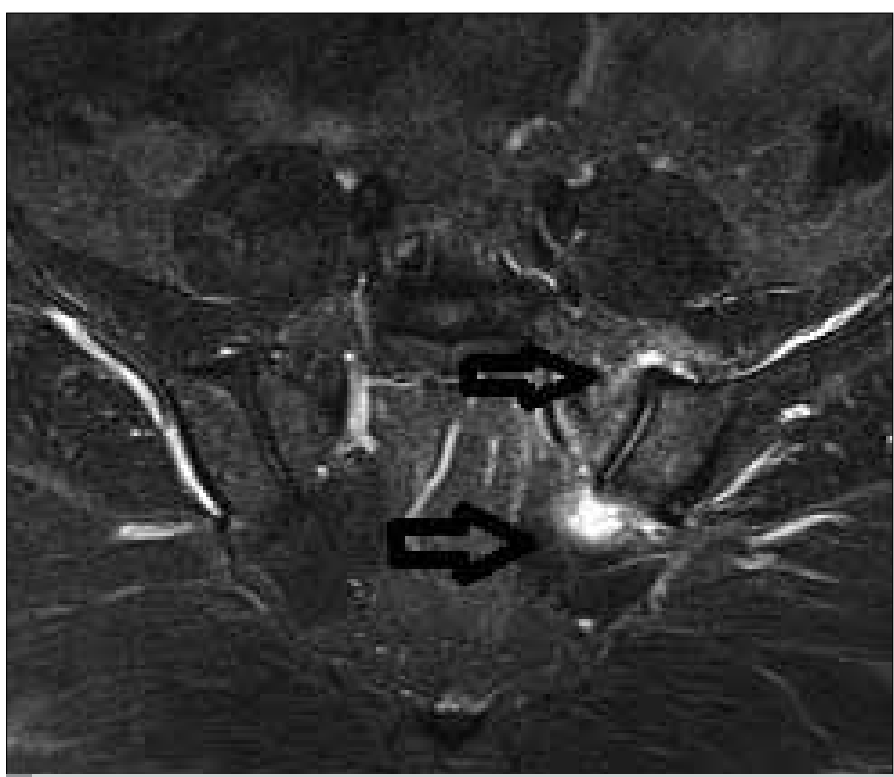

Sekil 2. Sakroiliak MR

\section{Tartışma}

Tüm dünyada yaygın olarak görülen Brusellozis özellikle Akdeniz ülkeleri, Arap yarımadası, Hindistan, Orta ve G. Amerika'da endemiktir $(5,6)$. En sık hastalık etkeni olan tür Brucella melitensis'dir (7). Brusellozis, çocukluk çağı dâhil her yaş grubunda görülebilir. Brusella basili hayvanlardan insanlara sıklıkla enfekte süt ya da süt ürünlerinin pastörize edilmeden tüketilmesi ile bulaşır. Nadiren enfekte materyalin direk teması ile ya da solunum yolları ile bulaşabilir $(3,8)$.

Brusellozis, genellikle ateş, halsizlik, gece terlemesi, eklem ağrısı, hepatosplenomegali ve lenfadenopati gibi semptomlarla akut olarak başlar $(1,6,8)$. Nadiren çeşitli romatizmal hastalıkları ve psikosomatik bozuklukları taklit eden sinsi bir başlangıç olabilir $(3,9)$. Brusellozis çok farklı klinik tablolara neden olabileceği için, özellikle endemik bölgelerde, farkı klinik tablolarla başvuran hastalarda brusellozis'in hatırlanması tanı için önemlidir.

Pek çok organ ve sistemleri tutabilen Brusellozis en sık retiküloendotelyal sistem ve kas iskelet sistemini tutar. Brusellozis vakalarının \%10-85'inde kas iskelet sistemi tutulumu vardır ve en sık karşılaşılan komplikasyonudur $(3,4,5)$. Sakroileit, spondilit, periferikartrit, osteomiyeliten sıkgörülen osteoartiküler tutulumlardır (4). Erişkinlerde en sık sakroileit görülür. Özellikle brusella mellitensis enfeksiyonlarında ortaya çıkan septik artrit ise nadir görülen bir komplikasyondur (2).

Brusella sakroileitinde, sakroiliak eklem ve kalça da şiddetli ağrı nedeniyle hastaların hareketleri kısıtlanmakta ve bazen hasta yatağa bağımlı hale gelmektedir. Doğru tanı koyulup, zamanında tedavi edilmezse ciddi mortaliteye neden olabilmektedir.

Brusellozis tedavisinde genellikle tetrasiklin, doksisiklin, streptomisin, rifampisin ve kotrimaksazol, kinolonlar, makrolid grubu ilaçlar ve kloramfenikol tercih edilir (10). Ancak brusella hücre içi 
mikroorganizma olduğu ve kolaylıklara ilaçlara direnç geliştirdiği için relapslar da sık görülmektedir. Özellikle monoterapilerde relapslar daha sıktır. Bu nedenle genellikle kombine tedaviler tercih edilmektedir. Osteoartiküler tutulumlarda daha başarılı oldukları için streptomisin, rifampisin ve doksosiklin 'den oluşan üçlü kombinasyonlar tercih edilmektedir $(2,5)$.

Bizim hastamıza dış merkezde ikili antibiyotik tedavisi (doksisiklin ve stretomisin) başlanmış, ancak şikayetleri ilerleyerek 10 gün içinde hasta tekerlekli sandalyeye bağımlı hale gelmişti. Hastanın tedavisine rifampisin eklenerek üçlü kombinasyon tedaviye geçildi. Sakroiliak abselerin küçük olması ve lokalizasyonu nedeniyle drenaj düşünülmedi.

Üçlü kombine tedavi ile hastanın klinik ve laboratuar bulguları düzeldi ve tekrar mobilize oldu. İdame tedavisi düzenlenerek taburcu edilen hasta, tedavi sonrası kontrollerine gelmediği için kontrol sakroiliak MRG çekilemedi.

Brusellaya bağlı akut sakroiliak abse gelişen ve ikili antibiyoterapiye rağmen klinik tablo ağırlaşarak tekerlekli sandalyeye bağımlı hale gelen bu vaka, nadir görülmesi ve üçlü tedaviye dramatik cevap vermesi nedeniyle sunulmuştur. Brusellanın nadirde olsa septik artrit yapabileceği ve doğru tedavi ile ciddi komplikasyonların önlenebileceğini akılda tutulmalıdır.

Not: Vaka takdimi anonim bir özellikte basılmak üzere hastaya ait gizli ve detaylı bilgiler kaldırılmıştır.

Informed consent: Patient consent was obtained because we could not reached patient.

Peer review: Externally peer-reviewed.

Author contributions: Concept - S.T.; Design - S.T.; Supervision - Ö.T.; Materials - S.T.; Data Collection and/or Processing - S.T.; Analysis and/ or Interpretation - S.T.; Literature Review - S.T.; Writer - S.T.; Critical Review - Ö.T.
Conflict of interest: The authors declared no conflict of interest.

Financial Disclosure: The authors declared that this study received no financial support.

Hasta Onamı: Hastaya ulaşılamadığı için onam alınamadı.

Hakem değerlendirmesi: Dış bağımsız.

Yazar Katkıları: Fikir - S.T.; Tasarım - S.T.; Denetleme - Ö.T.; Malzemeler - S.T.; Veri toplanması ve/veya işlemesi - S.T.; Analiz ve/veya yorum S.T.; Literatür taraması - S.T.; Yazıyı yazan - S.T.; Eleştirel Inceleme - Ö.T.

Çıkar Çatışması: Yazarlar çıkar çatışması bildirmemişlerdir.

Finansal Destek: Yazarlar finansal destek almadıklarını beyan etmişlerdir.

\section{Kaynaklar}

1. Corbel MJ. Brucellosis: an overview. Emerg Infect Dis 1997;3:213-21. [CrossRef]

2. Ozan F, Eryuva V, Koyuncu Ş, Bora OA, Avcı M. Brucella septic arthritis of the wrist. Ege Journal of Medicine 2013; 52: 61-5.

3. Tezer H, Kara A, Devrim I, Çağlar M, Şentürk S, Beşbaş N, et al. Brusella sakroilleitti: Bir vaka takdimi. Çocuk Sağlığı ve Hastalıkları Dergisi 2006; 49: 225-8.

4. Arkun R, Mete BD. Musculoskeletal brucellosis. Semin Musculoskelet Radiol. 2011; 15: 470-9. [CrossRef]

5. Geyik MF, Gur A, Nas K, Saraç J, Dikici B, Ayaz C. Musculoskeletal involvement of brucellosis in differentagegroups: A study of 195 cases. Swiss Med Wkly 2002; 132: 98-105.

6. Memish ZA, Balkhy HH. Brucellosis and international travel. J Travel Med 2004; 11: 49-55. [CrossRef]

7. Mousa AR, Muhtaseb SA, Almudallal DS, Khodeir MS, Marafie AA Osteoarticular complications of brucellosis: a study of 169 cases. Rev Infect Dis 1987; 9: 531-43. [CrossRef]

8. Pappas G, Akritidis N, Bosilkovski M, Tsianos E. Brucellosis. N Engl J Med 2005; 352: 2325-36. [CrossRef]

9. Young ES.Anoverview of human brucellosis. Clin InfectDis 1995;21:283. [CrossRef]

10. Akova M, Uzun O, Akalin HE, Hayran M, Unal S, Gur D. Quinolones in treatment of human brucellosis: comparativetrial of ofloxacin-rifampin versus doxycycline-rifampin. Antimicrobial Agents and Chemotherapy 1993; 37: 1831-34. [CrossRef] 